\title{
Design of Novel Helical Backbone. Conformational Energy Calculation and Synthesis of Sequential Polypeptide Containing $Z$-Dehydrophenylalanine and Proline Residues
}

\author{
Yoshihito InaI, ${ }^{\dagger}$ Yasuhiro Sakakura, ${ }^{*}$ and Tadamichi Hirabayashi \\ Department of Environmental Technology and Urban Planning, \\ Graduate School of Engineering, Nagoya Institute of Technology, \\ Gokiso-cho, Showa-ku, Nagoya 466, Japan \\ * Department of Materials Science and Engineering, \\ Nagoya Institute of Technology, Nagoya Institute of Technology, \\ Gokiso-cho, Showa-ku, Nagoya 466, Japan
}

(Received December 16, 1996)

\begin{abstract}
Theoretical conformational analysis was carried out on periodic polypeptides containing Z-dehydrophenylalanine ( $\left.\Delta^{Z} \mathrm{Phe}\right)$ and Pro residues, poly $\left(\mathrm{X}-\Delta^{Z}\right.$ Phe-Pro) $(\mathrm{X}=\mathrm{Ala}$, Leu, Gly, D-Ala, and aminoisobutyric acid (Aib)), using the procedure of conformational energy minimization. The lowest-energy conformations were found to be a right-handed $\beta^{11.9}$-helix for $\mathrm{X}=\mathrm{Ala}$, and a right-handed $\beta^{5.1}$-helix for $\mathrm{X}=\mathrm{Gly}$. For $\mathrm{X}=\mathrm{Leu}$, D-Ala, and Aib, the lowest-energy conformation was found to be a left-handed $\beta^{6.1-6.2}$-helix: the nearest phenyl-phenyl pairs took a center-to-center distance of $6.6-6.8 \AA$ and an edge-to-edge orientation. On the whole, phenyl groups were arranged in $\mathrm{C}_{2}$-type symmetry on the helical wheel. Poly(Leu- $\Delta^{Z}$ Phe-Pro) was synthesized by polymerizing the corresponding tripeptide with diphenylphosphoryl azide. The polypeptide in chloroform and in tetrahydrofuran showed a positive CD signal around $280 \mathrm{~nm}$, which is ascribed to the absorption band of $\Delta^{Z}$ Phe residue. This CD pattern means that the screw angle between neighboring $\Delta^{Z}$ Phe transition moments is around $0^{\circ}$ or $180^{\circ}$, suggesting the $\beta^{6}$-helical conformation predicted above.

KEY WORDS Sequential Polypeptide / Z-Dehydrophenylalanine / Proline / Conformational Energy Calculation / Synthesis / CD Study / $\beta$-Helix /
\end{abstract}

A synthetic helical polypeptide provides a rigid and regular backbone for arranging functional groups, which keep a specific distance and orientation between the neighboring ones. Thus the polypeptide has been widely applied to the construction of a model system ${ }^{1}$ for investigating a biological phenomena, and to the development of a new polymeric material. ${ }^{2}$ In most cases, such helical structure means $\alpha$-helix. Accordingly, molecular design in an $\alpha$-helical polypeptide has to be limited to its structural features (e.g., 3.6 residues per one turn). Helical backbones other than $\alpha$-helix are very important to design a wide variety of functional polypeptides.

Such other types of helices have been found experimentally and theoretically in periodic polypeptides: $\beta^{6}$ helix ${ }^{3,4}$ for poly(Ala-D-Ala); $\gamma$-helix, ${ }^{5} \beta$-helix, ${ }^{6}$ and $\beta$ spiral $^{7}$ for elastin model polypeptides such as poly(ValPro-Gly-Gly) and poly(Val-Pro-Gly-Val-Gly); $\beta^{6.8}$-helix for poly $(\text { Gly-Pro })^{8} ; \gamma$-helix for poly(Ala-Pro). ${ }^{9}$ Here $\beta^{X}$. helix is defined as a helix having spiral structure with $X$ residues per turn, and $\gamma$-helix is defined as a helix that cannot be categorized to the $\alpha$-and $\beta$-helices. ${ }^{4,5,10}$ In the above polypeptides, it should be noted that the repeating units contain non-L-Ala type of residues such as D-Ala, Gly, and Pro, which essentially differ from L-Ala-type of residues in conformational preference.

Recently we have focused on the conformational preference in $Z$-dehydrophenylalanine $\left(\Delta^{Z} \mathrm{Phe}\right)$ from the view point of peptide design. ${ }^{11-15}$

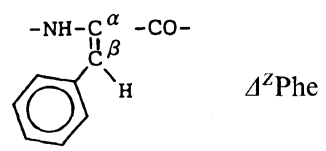

\footnotetext{
† To whom correspondence should be addressed.
}

This residue shows inherent conformational properties due to structural features, e.g., planarity of $\mathrm{C}^{\alpha}=\mathrm{C}^{\beta}$ double bond and trigonal geometry of $\mathrm{C}^{\alpha}$. Thus, periodic polypeptides containing dehydroresidues as non-L-Ala type of residues will be able to create new types of helical backbones. Also the $\Delta^{Z}$ Phe residue has a specific conformational space for its side chain. ${ }^{13-15}$ The freedom of side chain would be smaller than those of naturallyoccurring amino acids, such as Phe, Asp, Glu, and Lys, because the variable side-chain dihedral angle is regarded as single due to prohibited rotation about the $\mathrm{C}^{\alpha}=\mathrm{C}^{\beta}$ double bond. Accordingly, $\beta$-phenyl groups are tightly bound to a peptide backbone. Here $\beta$-phenyl group of $\Delta^{Z}$ Phe residue can be replaced by another functional group using DL- $\beta$-substituted Ser for a starting material in peptide synthesis. ${ }^{13}$ Therefore, $\beta$-substituted $\alpha, \beta$-dehydroalanines in periodic polypeptides are expected to be an unique residue for designing novel helical backbones to carry $\beta$-substituents in a spatially specific manner.

We already designed a right-handed $3_{10}$-helix using periodic (poly)peptides, (Ala- $\Delta^{Z}$ Phe-Aib) ${ }_{m}^{14,15}$ (Aib, aminoisobutyric acid) and (Leu- $\left.\Delta^{Z} \mathrm{Phe}\right)_{n}{ }^{11,12}$ In the present paper, periodic polypeptides containing $\Delta^{Z}$ Phe and Pro residues, poly(X- $\Delta^{Z}$ Phe-Pro), were adopted to demonstrate the possibility to form novel helical backbones. Theoretical conformational analysis was carried out on poly $\left(\mathrm{X}-\Delta^{Z}\right.$ Phe-Pro) (X=Ala, Leu, Gly, D-Ala, and $\mathrm{Aib}$ ), using the procedure of conformational energy minimization. Also, poly(Leu- $\Delta^{Z}$ Phe-Pro) I was synthesized and its CD spectra were measured: 


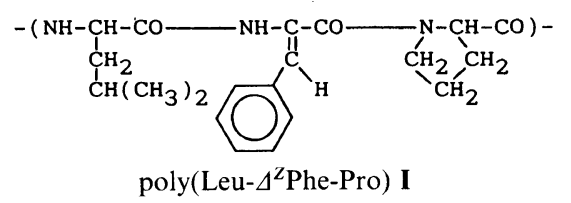

\section{EXPERIMENTAL}

\section{Conformational Energy Calculation}

Empirical conformational energy calculations were performed using energy functions of ECEPP system. ${ }^{16}$ Structural and energy parameters of $\Delta^{Z} \mathrm{Phe}$ were determined in previous studies. ${ }^{14,15}$ The program PEPCON, written by Sisido $^{17}$ for conformational energy calculation $^{16}$ and graphics ${ }^{18}$ of a given peptide, was modified to be applicable to $\Delta^{Z} \mathrm{Phe}$-containing peptides.

Conformational energy of poly(X- $\Delta^{Z}$ Phe-Pro) $(\mathrm{X}=$ Ala, Leu, Gly, D-Ala, and Aib) was calculated on Ac(X- $\Delta^{Z}$ Phe-Pro) ${ }_{8}$-NMA (Ac, acetyl; NMA, $N$-methylamide). Energy minimizations were carried out using the Simplex algorithm ${ }^{19}$ with the following variables: for the main chain, $(\phi, \psi)$ of $\mathrm{X},(\phi, \psi)$ of $\Delta^{\mathrm{Z}} \mathrm{Phe}, \psi$ of Pro, and for the side chain, $\chi^{2}$ of $\Delta^{Z}$ Phe and $\chi$ 's of $\mathrm{X}$ residue except for Gly ( $\chi^{1}$ for Ala and D-Ala, $\chi^{1}, \chi^{2}$, $\chi^{3,1}$ and $\chi^{3,2}$ for Leu, and $\chi^{1,1}$ and $\chi^{1,2}$ for Aib). $\psi$ of Pro was fixed to $-75^{\circ} .{ }^{20}$ Peptide bond of $\Delta^{Z}$ Phe-Pro linkage was taken to cis $\left(\omega=0^{\circ}\right)$ or trans conformation $\left(\omega=180^{\circ}\right)$. Based on crystallographic data of $\Delta^{Z} \mathrm{Phe}-$ containing peptides, ${ }^{21-24}$ the other peptide bonds were fixed to the trans conformation $\left(\omega=180^{\circ}\right)$, and each $\Delta^{Z}$ Phe side-chain $\left(\chi^{1}\right)$ was fixed to $0^{\circ}$.

The detailed procedure is shown on poly(Leu- $\Delta^{Z}$ PhePro) as follows. All possible conformations were searched by stepwise elongation of the repeating unit (Leu- $\Delta^{Z} \mathrm{Phe}$ Pro), as proposed by $\mathrm{Oka}^{4,5,8,9}$ In the first step, energy minimization for tripeptide, Ac-Leu- $\Delta^{Z}$ Phe-Pro-NMA, was carried out. Here all combinations of energy minima of Leu, $\Delta^{Z}$ Phe, and Pro residues $(81 \times 20 \times 6)$ were used as starting conformations. The second step was minimization of hexapeptide having two repeating units of Leu$\Delta^{Z}$ Phe-Pro, i.e., Ac-(Leu- $\Delta^{Z}$ Phe-Pro $)_{2}$-NMA. All minima in the first step were used as starting conformations for the second step. Also, the third step was minimization of Ac-(Leu- $\Delta^{Z}$ Phe-Pro $)_{4}$-NMA using all minima in the second step as starting conformations for the third step. Finally, the minimization of Ac-(Leu- $\Delta^{Z}$ Phe-Pro $)_{8}-$ NMA was carried out using all minima in the third step. The conformations obtained were also expressed by the conformational letter code that specifies 16 regions in conformational space. ${ }^{25}$

\footnotetext{
Measurement

${ }^{1} \mathrm{H}$ NMR spectra were recorded using a Varian UNITY plus $400(400 \mathrm{MHz})$ and a Hitachi R-90 spectrometer $(90 \mathrm{MHz})$. The measurements were carried out at peptide concentration of $20-40 \mathrm{mg} \mathrm{ml}^{-1}$ in $\mathrm{CDCl}_{3}$ at $298 \mathrm{~K}$. All chemical shifts in parts per million (ppm) were determined using tetramethylsilane as an internal standard. The pulse sequence for one-dimensional (1-D) $400 \mathrm{MHz}{ }^{1} \mathrm{H}$ NMR is as follows: $11.0-\mu$ s pulse width, 5.5-s acquisition time, and 7.5-s interval. Correlation spectroscopy (COSY) was performed using the standard
}

Varian software library, using 16 scans per $t_{1}, 2 \mathrm{~K}$ data points in the $t_{2}$ domain, and 512 points in the $t_{1}$ domain. IR spectra were recorded for samples cast on an $\mathrm{NaCl}$ plate using a Jasco IR Report 100 and a Nicolet Fourier transform infrared (FT-IR) spectrometer. CD and UV spectra were simultaneously recorded by using a JASCO $\mathrm{J}-600$ in chloroform and in tetrahydrofuran (THF). These solvents were purified by distillation before use.

\section{Materials}

Polypeptide I was synthesized by polymerizing the corresponding tripeptide, H-Leu- $\Delta^{Z}$ Phe-Pro-OH, with diphenylphosphoryl azide (DPPA). ${ }^{26}$ The $N$-protected peptide, Boc-Leu- $\Delta^{Z}$ Phe-Pro-OH (Boc, $t$-butoxycarbon$\mathrm{yl}$ ), was prepared by ring-opening Boc- $\Delta^{\mathrm{Z}} \mathrm{Phe}$ azlactone with amino group of Pro. The tripeptide was checked for purity by ${ }^{1} \mathrm{H}$ NMR and IR spectroscopy, thin-layer chromatography (TLC), and gel permeation chromatography (GPC). Solvent systems for TLC were (A) methanol, (B) chloroform-methanol (9:1), (C) n-butanolacetic acid-water $(7: 2: 1)$, and (D) ethyl acetate. The GPC was recorded on a Tosoh HLC-803-D equipped with G1000-, G2500-, and G3000-HXL columns in series, by using THF eluent. Single spot in the TLC and single peak in the GPC were obtained.

\section{Boc-Leu- $\Delta^{Z}$ Phe Azlactone}

The azlactone was prepared according to ref $22 . \mathrm{mp}$ $122-125^{\circ} \mathrm{C}\left(123-125^{\circ} \mathrm{C}\right) .^{23}$

\section{Boc-Leu- $\Delta^{Z}$ Phe-Pro- $O H$}

A precooled solution of Pro $(0.21 \mathrm{~g}, 1.8 \mathrm{mmol})$ in an aqueous solution of $\mathrm{NaOH}\left(1.0 \mathrm{~mol} \mathrm{ml}^{-1}, 1.8 \mathrm{ml}\right)$ was added to a solution of Boc-Leu- $\Delta^{Z}$ Phe azlactone $(0.50 \mathrm{~g}$, $1.4 \mathrm{mmol})$ in THF $(4 \mathrm{ml})$ at $0^{\circ} \mathrm{C}$. The mixture was stirred for $24 \mathrm{~h}$ at room temperature, and then neutralized with $5 \% \mathrm{KHSO}_{4}$ solution. The solvent was concentrated in vacuo, and the residue was acidified with $5 \% \mathrm{KHSO}_{4}$ solution and extracted with ethyl acetate. The extract was washed with saturated $\mathrm{NaCl}$ solution, dried over $\mathrm{MgSO}_{4}$, and evaporated in vacuo to give a white solid. Yield $0.65 \mathrm{~g}(98 \%)$. mp $110-115^{\circ} \mathrm{C} ; R_{\mathrm{f}}^{\mathrm{A}}=0.90 ; R_{\mathrm{f}}^{\mathrm{B}}=$ $0.28 ; R_{\mathrm{f}}^{\mathrm{C}}=0.91 ; R_{\mathrm{f}}^{\mathrm{D}}=0-0.16 .90 \mathrm{MHz}{ }^{1} \mathrm{H}$ NMR $(\delta$ in $\left.\mathrm{CDCl}_{3}\right): 8.38\left(1 \mathrm{H}, \mathrm{s}, \mathrm{NH} \Delta^{\mathrm{Z}} \mathrm{Phe}\right), 7.36(5 \mathrm{H}, \mathrm{s}$, phenyl $\mathrm{H}$ $\left.\Delta^{Z} \mathrm{Phe}\right), 6.24\left(1 \mathrm{H}, \mathrm{s}, \mathrm{C}^{\beta} \mathrm{H} \Delta^{\mathrm{Z}} \mathrm{Phe}\right), 5.12(1 \mathrm{H}$, br s, NH Leu), 4.60 (1H, t, $\mathrm{C}^{\alpha} \mathrm{H}$ Pro), $4.24\left(1 \mathrm{H}, \mathrm{m}, \mathrm{C}^{\alpha} \mathrm{H}\right.$ Leu $)$, $3.72\left(2 \mathrm{H}, \mathrm{m}, \mathrm{C}^{\delta} \mathrm{H}\right.$ Pro), $2.2\left(2 \mathrm{H}, \mathrm{m}, \mathrm{C}^{\gamma} \mathrm{H}_{2}\right.$ Pro), $2.0(2 \mathrm{H}$, $\mathrm{m}, \mathrm{C}^{\beta} \mathrm{H}_{2}$ Pro), $1.6\left(3 \mathrm{H}, \mathrm{m}, \mathrm{C}^{\beta} \mathrm{H}_{2}+\mathrm{C}^{\gamma} \mathrm{H}\right.$ Leu $), 1.42(9 \mathrm{H}$, $\left.\mathrm{s}, 3 \times \mathrm{CH}_{3} \mathrm{Boc}\right)$, and $0.92\left(6 \mathrm{H}, \mathrm{d}, 2 \times \mathrm{CH}_{3} \mathrm{Leu}\right)$. IR $\left(\mathrm{cm}^{-1}\right.$, on $\left.\mathrm{NaCl}\right): 3300(\mathrm{NH}), 1680 / 1640 / 1610(\mathrm{C}=\mathrm{O})$, and 1500 (NH).

\section{Polymerization}

Boc-Leu- $\Delta^{Z}$ Phe-Pro-OH $(0.97 \mathrm{~g}, 2.0 \mathrm{mmol})$ was dissolved in $\mathrm{HCOOH}(12 \mathrm{ml})$ at $0^{\circ} \mathrm{C}$ and allowed to stand for $22 \mathrm{~h}$ at room temperature. The mixture was concentrated in vacuo to give $\mathrm{HCOOH} \cdot \mathrm{H}-\mathrm{Leu}-\Delta^{Z} \mathrm{Phe}$-Pro$\mathrm{OH}$. The $\mathrm{HCOOH}$ salt was dissolved in a dioxane solution of $\mathrm{HCl}\left(0.20 \mathrm{~mol} \mathrm{ml}^{-1}, 25 \mathrm{ml}\right)$, and the mixture was evaporated in vacuo. This procedure was carried out again, and the resulting $\mathrm{HCl}$ salt was dried in vacuo. (Formyl proton at $c a .8 .0 \mathrm{ppm}$ in ${ }^{1} \mathrm{H}$ NMR spectrum of the residue was completely disappeared.) 
To a mixture of the salt and $N, N$-dimethylformamide (DMF) $(1.5 \mathrm{ml})$ were added DPPA $(0.57 \mathrm{ml}, 2.7 \mathrm{mmol})$ and triethylamine $(0.65 \mathrm{ml}, 4.7 \mathrm{mmol})$ at $5-10^{\circ} \mathrm{C}$. The mixture was stirred vigorously at $5-10^{\circ} \mathrm{C}$ for $2 \mathrm{~h}$, and stirring was continued for $140 \mathrm{~h}$. To the mixture was added a large volume of water, and the precipitate was collected by centrifugation, and dried in vacuo. Yield $0.70 \mathrm{~g}(93 \%)$. The obtained polypeptide was fractionated into species of $\mathrm{MW}=0.9 \times 10^{4}-1.8 \times 10^{4}$ (degree of polymerization $=25-50$ ) by column of TOYOPEARL $\mathrm{HW}-55 / \mathrm{DMF}$. The COSY spectrum is shown in Figure 1. $400 \mathrm{MHz}{ }^{1} \mathrm{H}$ NMR ( $\delta$ in $\left.\mathrm{CDCl}_{3}\right): 9.36(1 \mathrm{H}, \mathrm{s}, \mathrm{NH}$ $\left.\Delta^{Z} \mathrm{Phe}\right), 8.43(1 \mathrm{H}, \mathrm{s}, \mathrm{NH}$ Leu $), 7.23(2 \mathrm{H}, \mathrm{s}, o$-H of phenyl), $6.83(2 \mathrm{H}, \mathrm{s}, m-\mathrm{H}$ of phenyl), $6.43(1 \mathrm{H}, \mathrm{s}, p-\mathrm{H}$ of phenyl), $6.11\left(1 \mathrm{H}, \mathrm{s}, \mathrm{C}^{\beta} \mathrm{H} \Delta^{Z} \mathrm{Phe}\right), 4.64\left(1 \mathrm{H}, \mathrm{s}, \mathrm{C}^{\alpha} \mathrm{H}\right.$ Leu $), 4.40$ (1H, s, C ${ }^{\alpha} \mathrm{H}$ Pro), $3.70\left(2 \mathrm{H}, \mathrm{d}, \mathrm{C}^{\delta} \mathrm{H}_{2}\right.$ Pro), $2.50(2 \mathrm{H}, \mathrm{s}$, $\mathrm{C}^{\beta} \mathrm{H}_{2}$ Pro), 2.2-1.8 (3H, m, $\mathrm{C}^{\beta} \mathrm{H}_{2}-\mathrm{C}^{\gamma} \mathrm{H}$ Leu), 1.81
(2H, s, C $\mathrm{C}^{\gamma} \mathrm{H}_{2}$ Pro), and $1.12\left(6 \mathrm{H}, \mathrm{d}, \mathrm{CH}_{3} \times 2 \mathrm{Leu}\right)$. FTIR $\left(\mathrm{cm}^{-1}\right.$, on $\left.\mathrm{KBr}\right)$ : $3300(\mathrm{NH}), 1652 / 1614(\mathrm{C}=\mathrm{O})$, and $1530 / 1501 / 1483(\mathrm{NH})$.

\section{RESULTS AND DISCUSSION}

\section{Stable Conformations of poly $\left(X-\Delta^{Z}\right.$ Phe-Pro $)$}

Tables $\mathrm{I}-\mathrm{V}$ show energy-minimized conformations for poly $\left(\mathrm{X}-\Delta^{Z}\right.$ Phe-Pro $)$ of $\mathrm{X}=\mathrm{Ala}$, Leu, Gly, D-Ala, and Aib, respectively. Here the lowest- to 6th low-energy conformations are shown with the conformational letter code, helix-type, translation along helical axis per residue $(d)$, and energy difference per residue from the lowest energy $\left(\Delta E_{\text {res }}\right)$. All the conformations in Tables $\mathrm{I}-\mathrm{V}$ corresponded to $\beta$ - or $\gamma$-helix, indicating poly $\left(\mathrm{X}-\Delta^{Z}\right.$ PhePro) will be able to form an novel helical structure. The lowest-energy conformation for $\mathrm{X}=\mathrm{Ala}$ was predicted

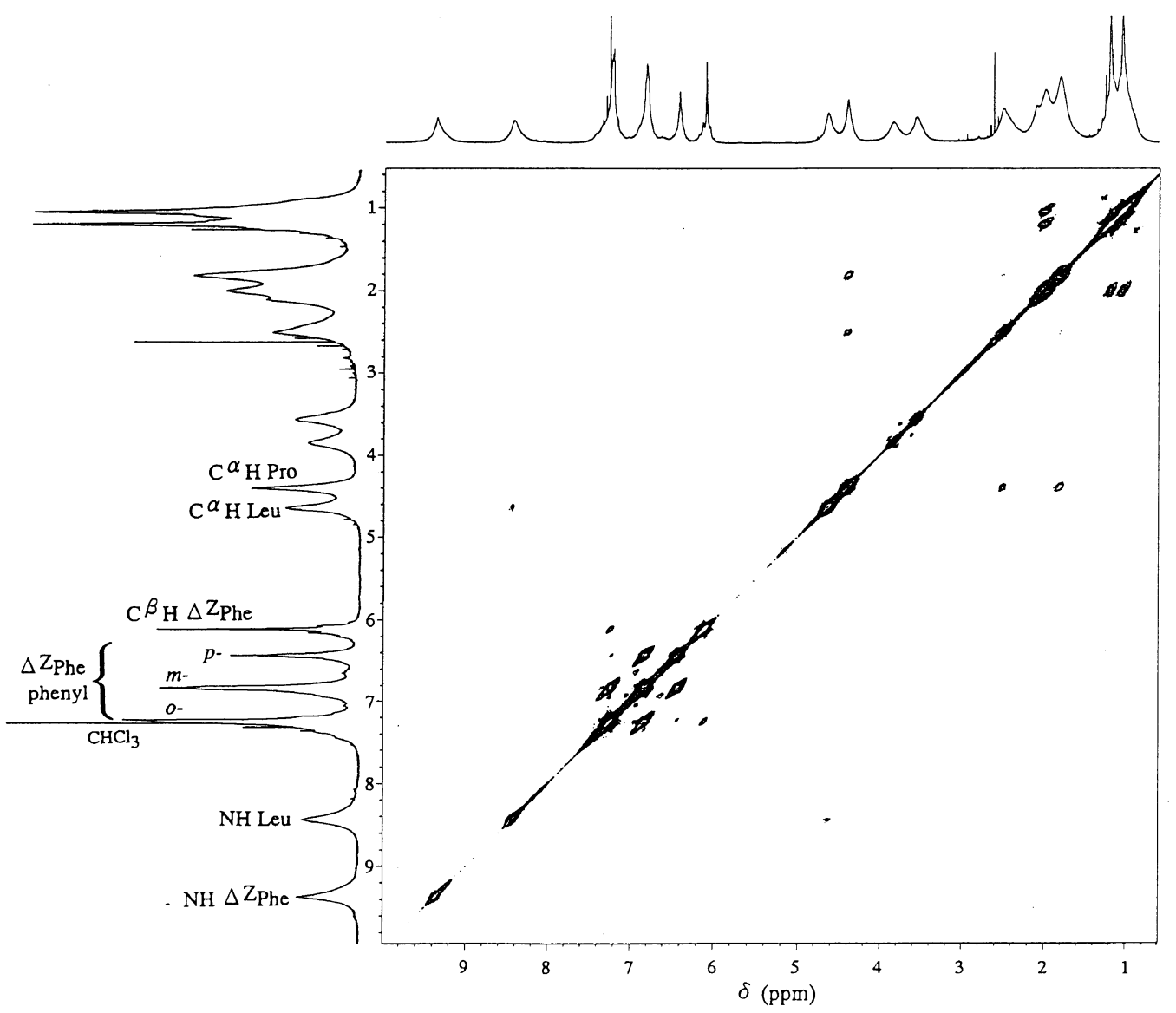

Figure 1. $400 \mathrm{MHz}$ COSY spectrum of polypeptide $\mathbf{I}$ in $\mathrm{CDCl}_{3}$.

Table I. Energy-minimized conformations for Ac-(Ala- $\Delta^{2}$ Phe-Pro $)_{8}$-NMA

\begin{tabular}{|c|c|c|c|c|c|c|c|c|c|c|}
\hline \multirow{2}{*}{$\begin{array}{l}\text { Conformational } \\
\text { letter code }\end{array}$} & \multirow{2}{*}{$\begin{array}{l}\text { Helix } \\
\text { type }^{a}\end{array}$} & \multirow{2}{*}{$\frac{d^{\mathrm{b}}}{\AA}$} & \multirow{2}{*}{$\begin{array}{c}R^{\mathrm{c}} \\
\AA\end{array}$} & \multicolumn{2}{|c|}{ Ala } & \multicolumn{3}{|c|}{$\Delta^{Z} \mathrm{Phe}$} & \multirow{2}{*}{$\begin{array}{c}\text { Pro }^{\mathrm{d}} \\
\psi\end{array}$} & \multirow{2}{*}{$\frac{\Delta E_{\mathrm{res}}^{\mathrm{e}}}{\mathrm{kcal} \mathrm{mol}^{-1}}$} \\
\hline & & & & $\phi$ & $\psi$ & $\phi$ & $\psi$ & $\chi^{2}$ & & \\
\hline DHC & $\beta^{11.9}(\mathrm{R})$ & 0.43 & 5.2 & -157 & 82 & -40 & -85 & 143 & 95 & 0.00 \\
\hline $\mathrm{A}^{*} \mathrm{H}^{*} \mathrm{~F}$ & $\beta^{6.2}(\mathrm{~L})$ & 1.10 & 6.7 & 58 & 35 & 122 & 105 & 142 & 150 & 0.24 \\
\hline FD*A & $\beta^{4.7}(\mathrm{R})$ & 1.56 & 9.8 & -90 & 141 & 126 & -89 & 136 & -50 & 0.76 \\
\hline$F D^{*} F^{f}$ & $\beta^{11.4}(\mathrm{R})$ & 1.15 & 9.0 & -72 & 132 & 131 & -77 & 137 & 139 & 0.78 \\
\hline $\mathrm{ED}^{*} \mathrm{~A}$ & $\beta^{4.7}(\mathrm{R})$ & 1.36 & 10.5 & -132 & 121 & 127 & -81 & 137 & -23 & 0.83 \\
\hline $\mathrm{CH}^{*} \mathrm{~A}^{\mathrm{f}}$ & $\gamma$ & 1.44 & 9.1 & -64 & 126 & 129 & 109 & 135 & -41 & 0.85 \\
\hline
\end{tabular}

${ }^{a} \mathrm{~L}$ and $\mathrm{R}$ are left- and right-handed helix sense, respectively. ${ }^{\mathbf{b}}$ Translation along helical axis per residue. ${ }^{\mathrm{c}}$ Center-to-center distance between the nearest $\beta$-phenyl pairs. ${ }^{\mathrm{d}} \phi=-75^{\circ} .{ }^{\mathrm{e}} \Delta E_{\mathrm{res}}=\left[E-E_{0}\right.$ (the lowest-energy) $] / 24 .{ }^{\mathrm{f}}$ cis-Peptide bond of $\Delta^{\mathrm{Z}}$ Phe-Pro linkage. 
Table II. Energy-minimized conformations for Ac-(Leu- $\Delta^{Z}$ Phe-Pro) $)_{8}$-NMA

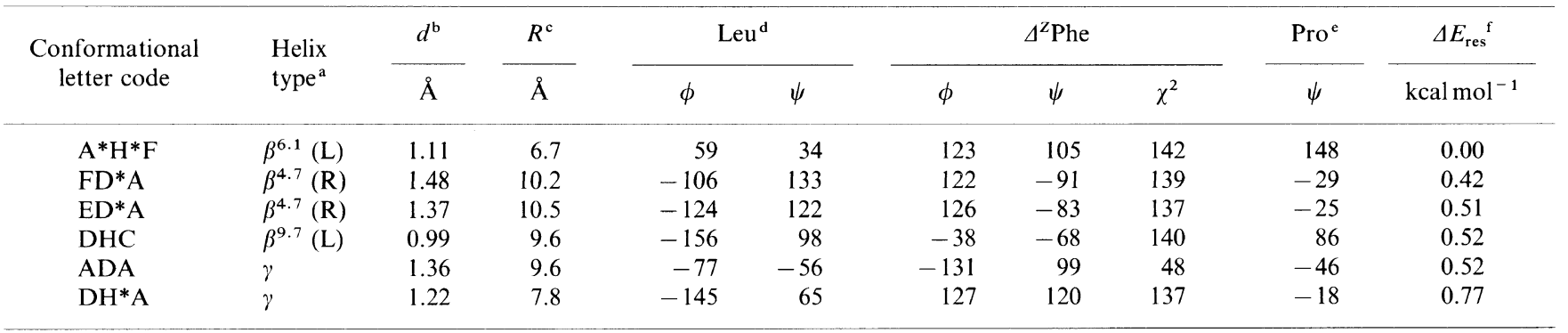

${ }^{\mathrm{a}} \mathrm{L}$ and $\mathrm{R}$ are left- and right-handed helix sense, respectively. ${ }^{\mathrm{b}}$ Translation along helical axis per residue. ${ }^{\mathrm{c}} \mathrm{Center-to-center} \mathrm{distance} \mathrm{between}$ the nearest $\beta$-phenyl pairs. ${ }^{\mathrm{d}}$ For each letter code, the most stable orientation in Leu's side chain $\left(\chi^{1}, \chi^{2}, \chi^{3,1}\right.$, and $\left.\chi^{3,2}\right)$ is shown here. ${ }^{\mathrm{e}} \phi=-75^{\circ}$. ${ }^{\mathrm{f}} \Delta E_{\mathrm{res}}=\left[E-E_{0}(\right.$ the lowest-energy $\left.)\right] / 24$.

Table III. Energy-minimized conformations for Ac-(Gly- $\Delta^{Z}$ Phe-Pro $)_{8}$-NMA

\begin{tabular}{|c|c|c|c|c|c|c|c|c|c|c|}
\hline \multirow{2}{*}{$\begin{array}{l}\text { Conformational } \\
\text { letter code }\end{array}$} & \multirow{2}{*}{$\begin{array}{l}\text { Helix } \\
\text { type }^{a}\end{array}$} & \multirow{2}{*}{$\frac{d^{\mathrm{b}}}{\AA}$} & \multirow{2}{*}{$\frac{R^{\mathrm{c}}}{\AA}$} & \multicolumn{2}{|c|}{ Gly } & \multicolumn{3}{|c|}{$\Delta^{Z}$ Phe } & \multirow{2}{*}{$\frac{\text { Pro }^{\mathrm{d}}}{\psi}$} & \multirow{2}{*}{$\frac{\Delta E_{\mathrm{res}}^{\mathrm{e}}}{\mathrm{kcal} \mathrm{mol}^{-}}$} \\
\hline & & & & $\phi$ & $\psi$ & $\phi$ & $\psi$ & $\chi^{2}$ & & \\
\hline $\mathrm{A}^{*} \mathrm{EC}$ & $\beta^{5.1}(\mathrm{R})$ & 1.07 & 7.8 & 80 & 23 & -130 & 115 & 48 & 77 & 0.00 \\
\hline $\mathrm{A}^{*} \mathrm{H}^{*} \mathrm{~F}$ & $\beta^{6.1}(\mathrm{~L})$ & 1.13 & 6.8 & 70 & 29 & 129 & 109 & 137 & 137 & 0.01 \\
\hline AAA & $\gamma$ & 1.46 & 7.2 & -65 & -43 & -42 & -72 & 134 & -17 & 0.16 \\
\hline $\mathrm{A}^{*} \mathrm{HC}$ & $\gamma$ & 1.50 & 8.2 & 87 & 40 & -125 & -97 & 40 & 106 & 0.38 \\
\hline $\mathrm{A}^{*} \mathrm{H}^{*} \mathrm{C}$ & $\beta^{11.7}(\mathrm{~L})$ & 1.12 & 5.7 & 88 & 13 & 31 & 78 & 46 & 100 & 0.59 \\
\hline
\end{tabular}

${ }^{\mathrm{a}} \mathrm{L}$ and $\mathrm{R}$ are left- and right-handed helix sense, respectively. ${ }^{\mathrm{b}}$ Translation along helical axis per residue. ${ }^{\mathrm{c}}$ Center-to-center distance between the nearest $\beta$-phenyl pairs. ${ }^{\mathrm{d}} \phi=-75^{\circ} .{ }^{\mathrm{e}} \Delta E_{\mathrm{res}}=\left[E-E_{0}(\right.$ the lowest-energy $\left.)\right] / 24$.

Table IV. Energy-minimized conformations for Ac-(D-Ala- $\Delta^{Z}$ Phe-Pro) $)_{8}$ NMA

\begin{tabular}{|c|c|c|c|c|c|c|c|c|c|c|}
\hline \multirow{2}{*}{$\begin{array}{l}\text { Conformational } \\
\text { letter code }\end{array}$} & \multirow{2}{*}{$\begin{array}{l}\text { Helix } \\
\text { type }^{\text {a }}\end{array}$} & \multirow{2}{*}{$\frac{d^{\mathrm{b}}}{\AA}$} & \multirow{2}{*}{$\frac{R^{\mathrm{c}}}{\AA}$} & \multicolumn{2}{|c|}{ D-Ala } & \multicolumn{3}{|c|}{$\Delta^{Z} \mathrm{Phe}$} & \multirow{2}{*}{$\frac{\operatorname{Pro}^{\mathrm{d}}}{\psi}$} & \multirow{2}{*}{$\frac{\Delta E_{\mathrm{res}}^{\mathrm{e}}}{\mathrm{kcal} \mathrm{mol}^{-1}}$} \\
\hline & & & & $\phi$ & $\psi$ & $\phi$ & $\psi$ & $\chi^{2}$ & & \\
\hline$D^{*} D^{f}$ & $\gamma$ & 1.36 & 8.9 & 158 & -67 & -132 & 101 & 46 & 168 & 0.48 \\
\hline $\mathrm{G}^{*} \mathrm{D}^{*} \mathrm{C}$ & $\beta^{5.4}(\mathrm{R})$ & 1.02 & 7.7 & 138 & 55 & 122 & -109 & 137 & 90 & 0.61 \\
\hline$C^{*} \mathrm{DC}$ & $\beta^{6.1}(\mathrm{~L})$ & 1.41 & 8.5 & 90 & -70 & -127 & 108 & 43 & 118 & 0.87 \\
\hline $\mathrm{E}^{*} \mathrm{AC}$ & $\beta^{6.6}(\mathrm{R})$ & 1.06 & 7.6 & 163 & -165 & -40 & -66 & 140 & 81 & 1.01 \\
\hline$C^{*} D^{*} \mathrm{~F}$ & $\beta^{8.4}(\mathrm{~L})$ & 0.78 & 7.6 & 103 & -67 & 128 & -109 & 131 & 161 & 1.13 \\
\hline
\end{tabular}

${ }^{\mathrm{a}} \mathrm{L}$ and $\mathrm{R}$ are left- and right-handed helix sense, respectively. ${ }^{\mathrm{b}}$ Translation along helical axis per residue. ${ }^{\mathrm{c}}$ Center-to-center distance between the nearest $\beta$-phenyl pairs. ${ }^{\mathrm{d}} \phi=-75^{\circ} .{ }^{\mathrm{e}} \Delta E_{\mathrm{res}}=\left[E-E_{0}\right.$ (the lowest-energy) $] / 24 .{ }^{\mathrm{f}}$ cis-Peptide bond of $\Delta^{\mathrm{Z}}$ Phe-Pro linkage.

Table V. Energy-minimized conformations for Ac-(Aib- $\Delta^{Z}$ Phe-Pro) ${ }_{8}$-NMA

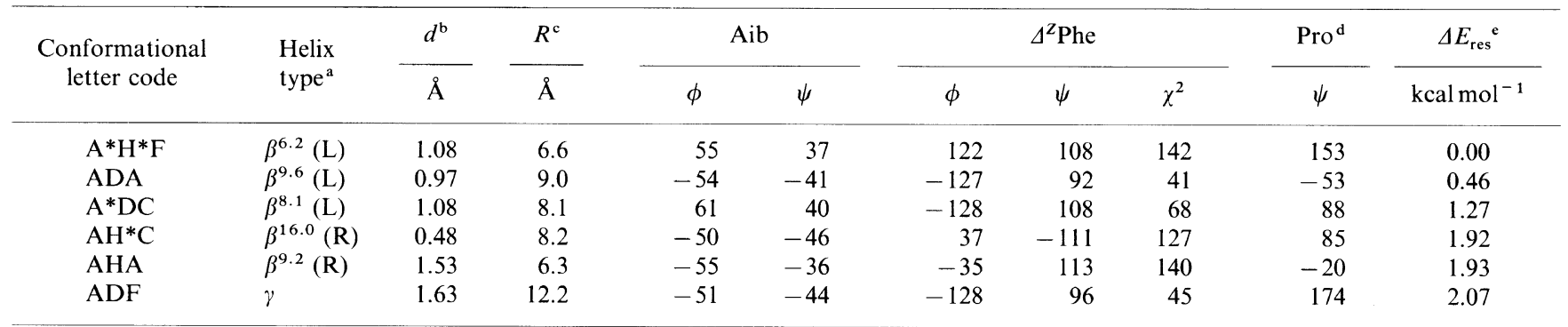

${ }^{a} \mathrm{~L}$ and $\mathrm{R}$ are left- and right-handed helix sense, respectively. ${ }^{\mathrm{b}}$ Translation along helical axis per residue. ${ }^{\mathrm{c}}$ Center-to-center distance between the nearest $\beta$-phenyl pairs. ${ }^{\mathrm{d}} \phi=-75^{\circ} .{ }^{\mathrm{e}} \Delta E_{\mathrm{res}}=\left[E-E_{0}\right.$ (the lowest-energy) $] / 24$.

to be a letter code of $\mathrm{DHC}$, which is a right-handed $\beta^{11.9}$-helix, as shown in Figure 2. The nearest phenylphenyl pairs took a center-to-center distance of $5.2 \AA$ and a face-to-face orientation. On the whole, phenyl groups were arranged in $\mathrm{C}_{4}$-type symmetry on the helical wheel. For $\mathrm{X}=\mathrm{Gly}$, the lowest-energy conformation was a letter code of $\mathrm{A}^{*} \mathrm{EC}$, which is a right-handed $\beta^{5.1}$-helix, as shown in Figure 3. A left-handed $\beta^{6.1-6.2}$-helix appeared as the lowest-energy conformation for $\mathrm{X}=\mathrm{Leu}$, D-Ala, and Aib, as shown in Figure $4(X=L e u)$. Similar $\beta^{6}$-helix was also seen as 2 nd low-energy conformation for $\mathrm{X}=\mathrm{Ala}$ and Gly. The nearest phenyl-phenyl pairs took a center-to-center distance of $6.6-6.8 \AA$ and an edge-to-edge orientation. On the whole, phenyl groups 


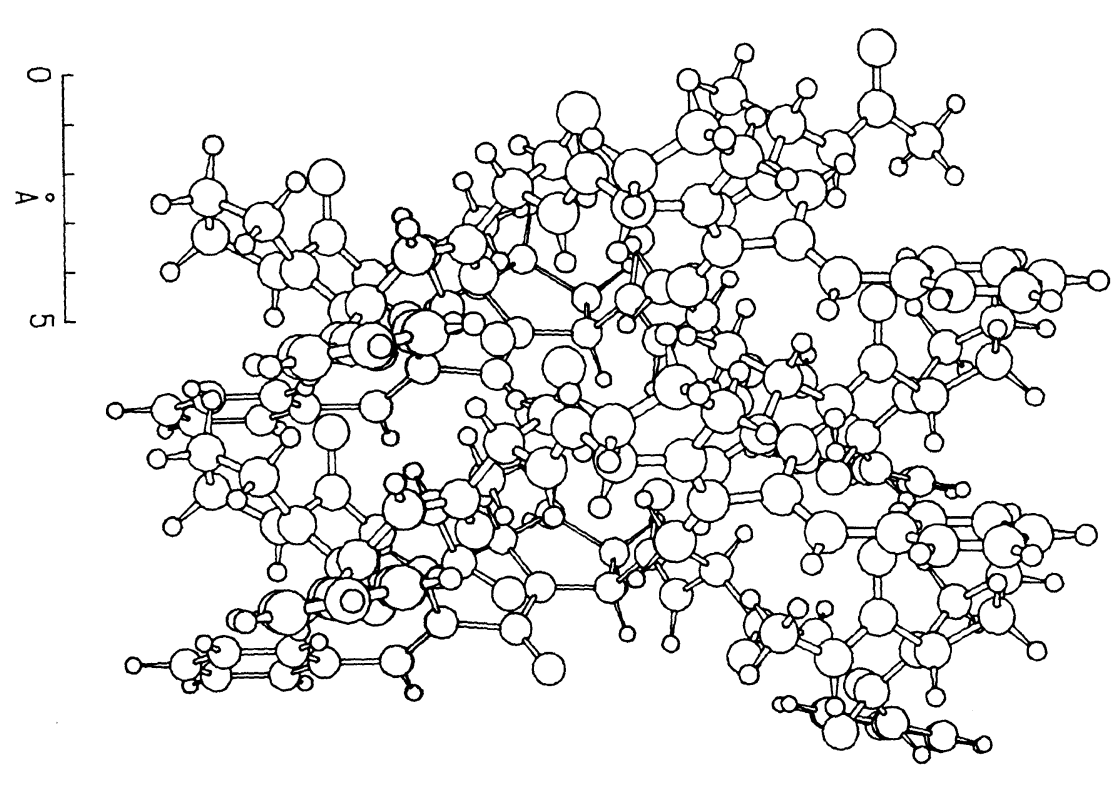

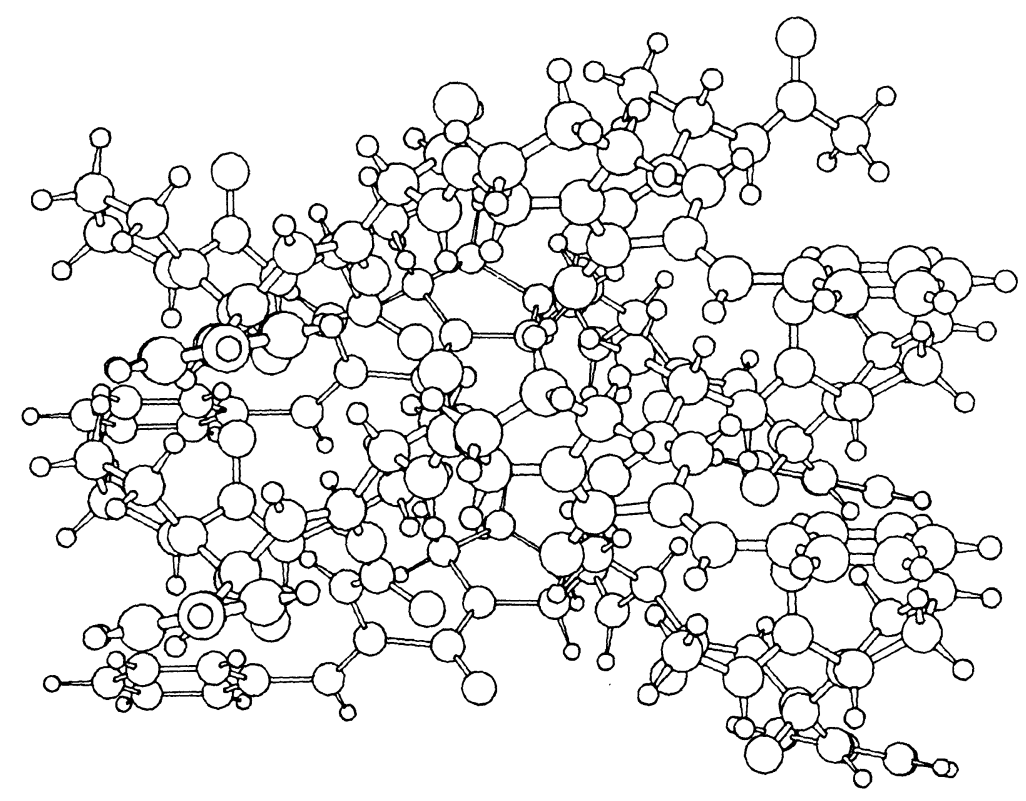

(a)

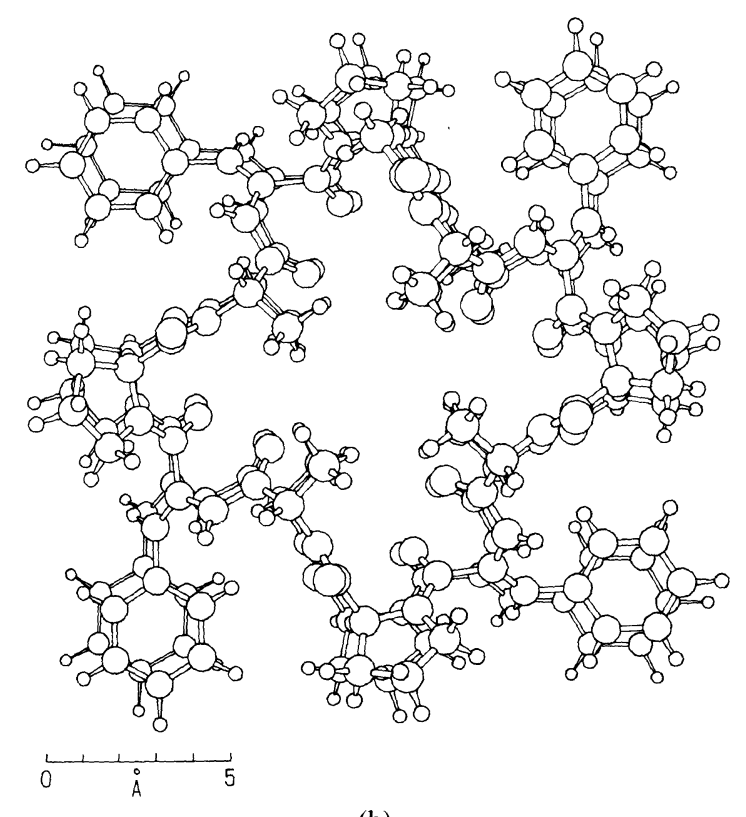




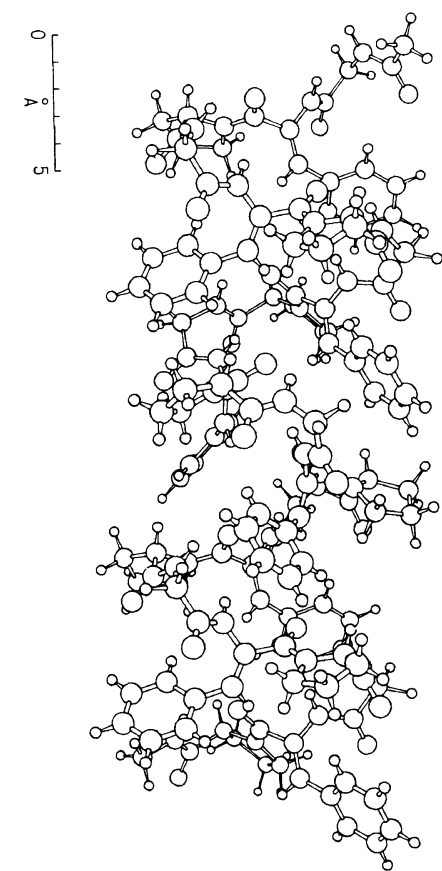

(a)

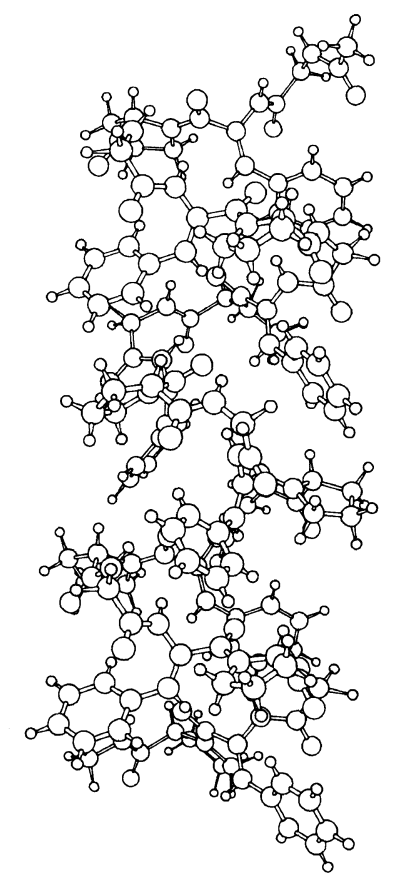

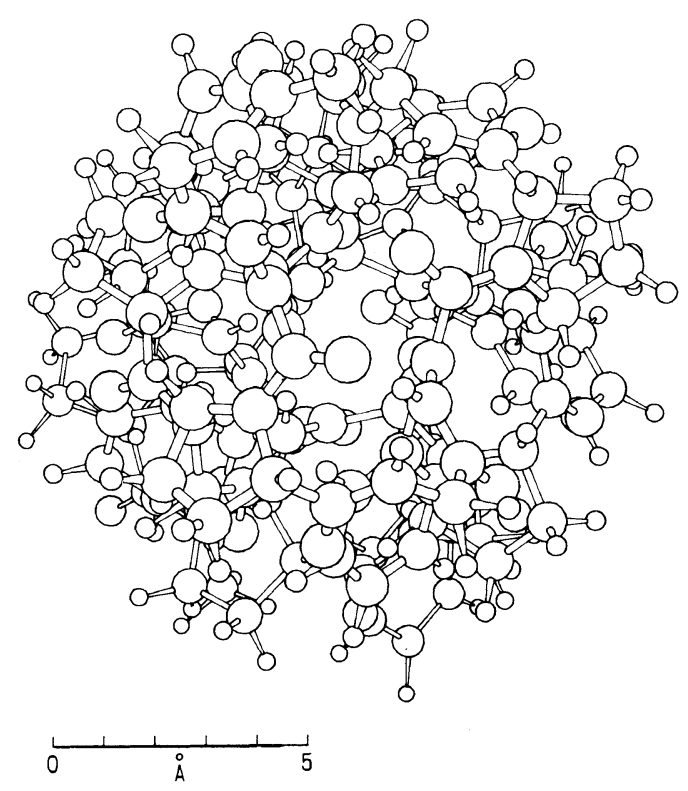

(b)

Figure 3. The lowest-energy conformation (a right-handed $\beta^{5.1}$-helix) of poly(Gly- $\Delta^{Z}$ Phe-Pro): (a) side-view; (b) top-view.

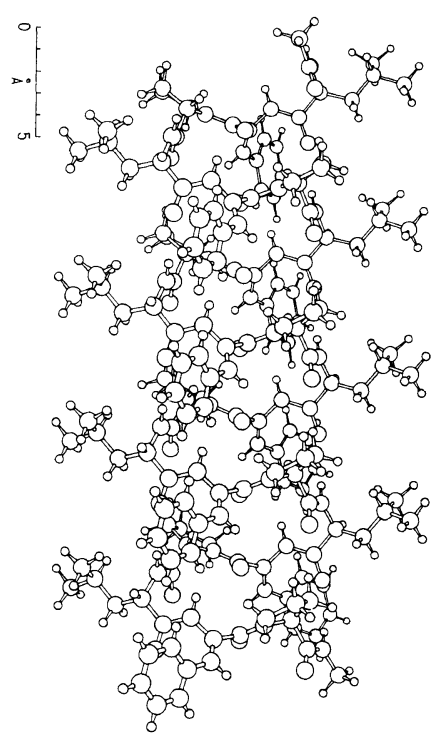

(a)

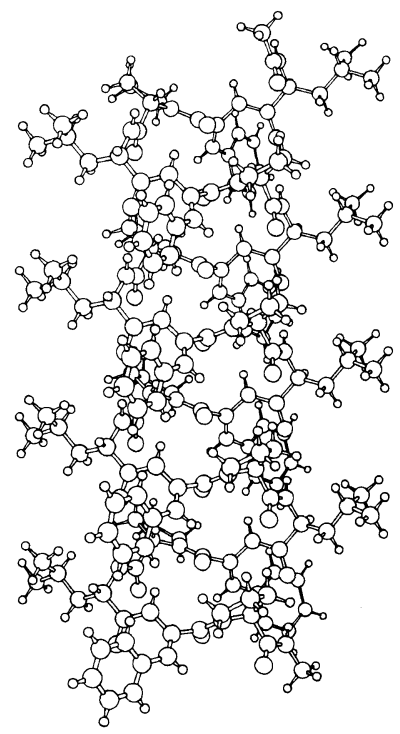

(a)

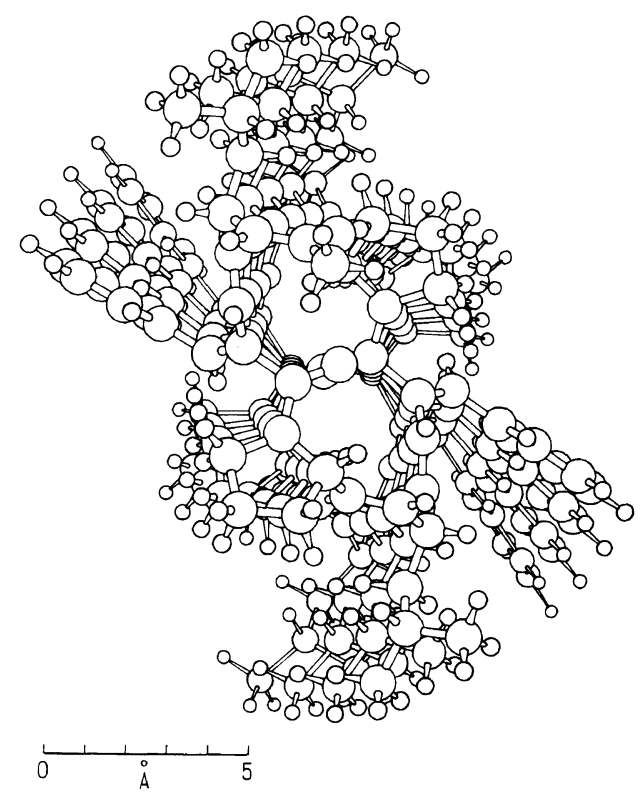

(b)

Figure 4. The lowest-energy conformation (a left-handed $\beta^{6.1}$-helix) of poly(Leu- $\Delta^{Z}$ Phe-Pro): (a) side-view; (b) top-view.

were arranged in $\mathrm{C}_{2}$-type symmetry on the helical wheel. For $\mathrm{X}=\mathrm{Leu}$, D-Ala, and Aib, marked energy difference between the lowest- and 2nd low-energy helical conformations $\left(>0.4 \mathrm{kcal} \mathrm{mol}^{-1}\right.$ ) was seen, suggesting that the lowest-energy conformation is relatively stable. Thus, polypeptide I for $\mathrm{X}=$ Leu was synthesized here.

Novel helical conformations found in poly $\left(\mathrm{X}-\Delta^{Z} \mathrm{Phe}-\right.$ Pro) should be mainly ascribed to the presence of Pro residue in the repeating units, since the lowest-energy conformation of Ac-(Ala- $\left.\Delta^{Z} \mathrm{Phe}-\mathrm{Aib}\right)_{8}-\mathrm{NMA}^{15}$ and Ac(Ala- $\left.\Delta^{Z} \mathrm{Phe}\right)_{12}$-NMA $^{12}$ showed an $\alpha$-helical conformation. Table VI shows energy-minimized conformations of Ac-(Phe-Pro-Ala) $)_{8}-\mathrm{NMA},{ }^{27}$ in which $\Delta^{Z}$ Phe residue in Ac-(Ala- $\Delta^{Z}$ Phe-Pro) ${ }_{8}$-NMA is replaced by the cor- responding saturated residue. The lowest-energy conformation was a left-handed $\beta^{10.5}$-helix (DAA), being different from $\beta^{11.9}$-helix of the lowest-energy for Ac(Ala- $\Delta^{Z}$ Phe-Pro) ${ }_{8}$-NMA. On the other hand, the $\beta^{11.9}$ helix resembles a left-handed $\beta^{12.0}$-helix of the lowestenergy for poly(Ala-Pro-Phe). ${ }^{28}$ From comparison of Tables I and VI, energy-minimized conformations of Ac-(Ala- $\Delta^{Z}$ Phe-Pro) ${ }_{8}$-NMA differs from Ac-(Phe-ProAla) $)_{8}$-NMA essentially. Therefore, the introduction of $\Delta^{Z}$ Phe residue to Pro-containing polypeptides should vary their conformational space to create a novel helical backbone. 
Table VI. Energy-minimized conformations for Ac-(Phe-Pro-Ala) ${ }_{8}-\mathrm{NMA}^{27}$

\begin{tabular}{|c|c|c|c|c|c|c|c|c|}
\hline \multirow{2}{*}{$\begin{array}{l}\text { Conformational } \\
\text { letter code }\end{array}$} & \multirow{2}{*}{$\begin{array}{l}\text { Helix } \\
\text { type }^{\mathrm{a}}\end{array}$} & \multirow{2}{*}{$\frac{d^{\mathrm{b}}}{\AA}$} & \multicolumn{2}{|c|}{ Phe } & \multirow{2}{*}{$\begin{array}{c}\text { Pro }^{c} \\
\psi\end{array}$} & \multicolumn{2}{|c|}{ Ala } & \multirow{2}{*}{$\frac{\Delta E_{\mathrm{res}}^{\mathrm{f}}}{\mathrm{kcal} \mathrm{mol}^{-1}}$} \\
\hline & & & $\phi$ & $\psi$ & & $\phi$ & $\psi$ & \\
\hline DCA & $\beta^{13.8}(\mathrm{R})$ & 0.48 & -146 & 82 & 86 & -71 & -35 & 0.63 \\
\hline DCG & $\beta^{8.7}(\mathrm{~L})$ & 1.54 & -154 & 79 & 82 & -159 & -57 & 0.64 \\
\hline DCG & $\beta^{8.1}(\mathrm{~L})$ & 1.43 & -146 & 79 & 68 & -169 & -53 & 0.84 \\
\hline DFA* $^{*}$ & $\beta^{11.6}(\mathrm{R})$ & 0.72 & -158 & 93 & 178 & 57 & 53 & 0.98 \\
\hline $\mathrm{DCA}^{*}$ & $\beta^{8.2}(\mathrm{~L})$ & 1.22 & -152 & 84 & 96 & 62 & 50 & 1.02 \\
\hline DBA & $\beta^{10.1}(\mathrm{R})$ & 1.24 & -156 & 82 & -9 & -60 & -45 & 1.04 \\
\hline EAG & $\gamma$ & 1.74 & -152 & 158 & -27 & -143 & -57 & 1.34 \\
\hline
\end{tabular}

${ }^{\mathrm{a}} \mathrm{L}$ and $\mathrm{R}$ are left- and right-handed helix sense, respectively. ${ }^{\mathrm{b}}$ Translation along helical axis per residue. ${ }^{\mathrm{c}} \phi=-75^{\circ} .{ }^{\mathrm{d}} \Delta E_{\mathrm{res}}=\left[E_{-}-E_{0}(\right.$ the lowest-energy)]/24.

\section{Spectra of $\mathbf{I}$}

Figure 5 shows CD and UV spectra of polypeptide I in chloroform and in THF. Polypeptide I was partly or not soluble in polar solvents such as methanol and acetonitrile. The molar extinction coefficients $(\varepsilon)$ and $\Delta \varepsilon$ $\left(=\varepsilon_{\mathbf{L}}-\varepsilon_{\mathbf{R}}\right)$ are expressed with respect to molar concentration of the $\Delta^{Z}$ Phe residue. UV absorption spectra showed intense maxima around $280 \mathrm{~nm}$ assignable to $\Delta^{\mathrm{Z}} \mathrm{Phe}$ residue. The UV pattern was essentially similar to that of Boc-Leu- $\Delta^{Z}$ Phe-Pro-OH II, indicating that no strong ground-state interaction between $\Delta^{Z} \mathrm{Phe}-\Delta^{Z} \mathrm{Phe}$ pairs exists in polypeptide $\mathbf{I}$.

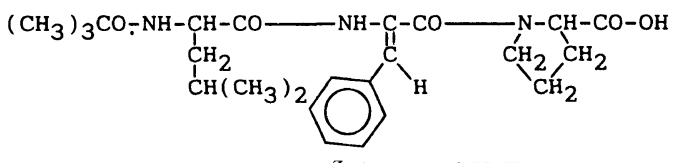

Boc-Leu- $\Delta^{Z}$ Phe-Pro-OH II

The corresponding CD spectra of polypeptide $\mathbf{I}$ in the two solvents showed a positive band around $280 \mathrm{~nm}$. Compared with polypeptide I, peptide II showed somewhat smaller CD intensity and more marked solvent dependence on its CD pattern, suggesting that polypeptide I takes a more defined conformation. Poly[Lys $(\mathrm{Z})-\Delta^{Z}$ Phe-Aib] [Lys $(\mathrm{Z}), N^{\varepsilon}$-[(benzyloxy)carbonyl]L-lysine] that takes a right-handed $30^{-}$or $\alpha$-helix in chloroform showed an exciton splitting in correspondence of the $280-\mathrm{nm}$ transition, with a negative peak at longer wavelengths. ${ }^{15}$ Thus, polypeptide I should take a conformation other than $30^{-}$or $\alpha$-helix essentially. Non-split CD pattern indicates that dipole-dipole interactions between $\Delta^{Z}$ Phe residues are weak in polypeptide I. The direction of the $280-\mathrm{nm}$ transition moment is assigned to the intramolecular charge-transfer between the styryl and carbonyl groups in $\Delta^{Z}$ Phe residue. ${ }^{14,29}$ The transition moment was estimated from molecular orbital calculation to lie on the phenyl-carbonyl line, as shown in Figure 6(a). ${ }^{14}$ By applying the exciton chirality method $^{30}$ to the present system, non-split CD pattern should mean that the skew angle between neighboring transition moments $(\tau)$ is $\sim 0^{\circ}$ or $\sim 180^{\circ}$, i.e., a parallel arrangement of the moments along peptide backbone as shown in Figure 6(b). This arrangement might correspond to the spatial arrangement of $\Delta^{Z}$ Phe side chains on the $\beta^{6}$-helical, as shown in Figure $4(\mathrm{~b})$.

The parallel arrangement estimated from non-split

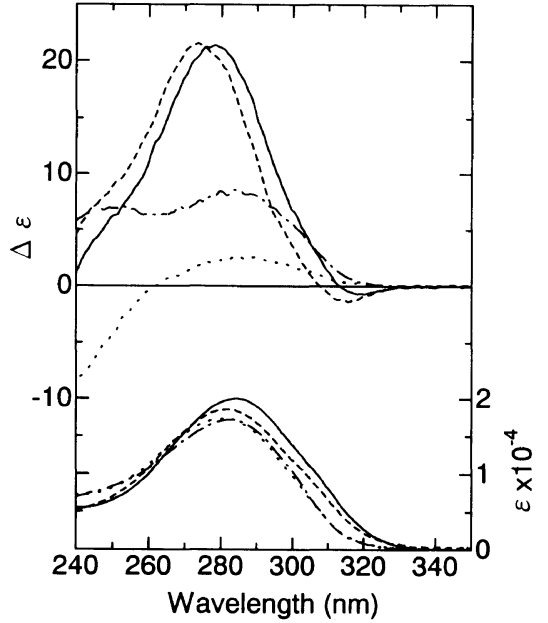

Figure 5. CD (top) and UV absorption (bottom) spectra of polypeptide I and peptide II: I ( $(-)$ and II (.....) in chloroform; I (---) and II (-.-) in THF.
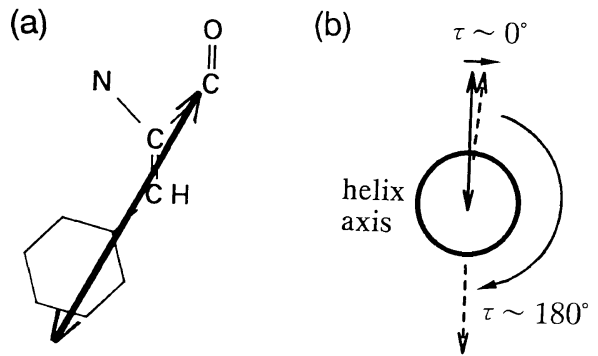

Figure 6. (a) The location of the $280 \mathrm{~nm}$-transition moment of $\Delta^{\mathrm{Z}} \mathrm{Phe}$ residue. (b) The relative orientation between neighboring moments on a helical wheel $\left(\tau=\sim 0^{\circ}\right.$ and $\left.\sim 180^{\circ}\right)$.

CD pattern was supported by CD spectrum of Boc-Val$\Delta^{Z}$ Phe-Phe-Ala-Leu-Ala- $\Delta^{Z}$ Phe-Leu-OMe that take an $\alpha$-helical structure in chloroform. ${ }^{31}$ Namely, only an intense positive band was observed for the above peptide in chloroform. ${ }^{32}$ Here the two $\Delta^{Z}$ Phe side chains are located nearly in the opposite site of $\alpha$-helical wheel, i.e., $\tau \sim 0^{\circ}$.

In the above discussion, peptide bond of $\Delta^{Z}$ Phe-Pro linkage has been fixed at $180^{\circ}$ (trans). The NMR spectrum of polypeptide I (Figure 1) showed a single peak for Pro $\mathrm{H}^{\alpha}$ at $4.40 \mathrm{ppm}$, indicating that $\Delta^{Z}$ Phe-Pro bond was taken to be either cis- or trans-form. ${ }^{33}$ The position was close to $4.43 \mathrm{ppm}$ of Pro $\mathrm{H}^{\alpha}$ for $3_{10}$-helical Boc- 
(Val) $)_{2}$-Aib-trans-Pro-(Val) ${ }_{3}-\mathrm{OMe}$ in $\mathrm{CDCl}_{3} .{ }^{34}$ The trans-form of $\Delta^{Z}$ Phe-Pro linkage was also supported by the conformational energies between Ac-(Leu- $\Delta^{Z}$ Phecis-Pro $)_{8}$-NMA and Ac-(Leu- $\Delta^{Z}$ Phe-trans-Pro) ${ }_{8}$-NMA: the lowest-energy cis-form was $0.96 \mathrm{kcal}^{\mathrm{mol}}$ (residues) ${ }^{-1}$ higher than the lowest-energy trans-form, being markedly unstable.

Further evidence is necessary to confirm the presence of $\beta$-helix in polypeptide I. We will perform NMR and $\mathrm{X}$-ray analysis to determine more precise conformation. However, the present study demonstrated the possibility to design and synthesize a novel helical backbone using sequential polypeptides containing $\Delta^{Z} \mathrm{Phe}$ and Pro residues.

Acknowledgment. We express our sincere gratitude to Professor M. Kawai in Department of Applied Chemistry, Nagoya Institute of Technology for the use of CD apparatus.

\section{REFERENCES}

1. M. Sisido, Y. Inai, and Y. Imanishi, "Fundamental Investigations on the Creation of Biofunctional Materials," S. Okamura, T. Tsuruta, Y. Imanishi, and J. Sunamoto, Ed., Kagaku-Dojin, Kyoto Japan, 1991, pp 183-196, and references therein.

2. M. Iwatsuki, Kobunshi, 39, 532 (1990), and references therein

3. D. W. Urry, Proc. Natl. Acad. Sci. U.S.A., 69, 1610 (1972).

4. M. Oka, Y. Baba, Y. Kagemoto, and A. Nakajima, Polym. J., 22, 135 (1990).

5. M. Oka, Y. Baba, A. Kagemoto, and A. Nakajima, Polym. J., 22, 555 (1990).

6. M. Oka and A. Nakajima, Peptide Chem., 1992, 275 (1993).

7. C. M. Venkatachalam and D. W. Urry, Macromolecules, 14, 1225 (1981).

8. M. Oka and A. Nakajima, Polym. Bull., 30, 647 (1993).

9. M. Oka and A. Nakajima, Polym. Bull., 33, 693 (1994).

10. M. Oka, Y. Baba, Y. Kagemoto, and A. Nakajima, Polym. J., 22, $416(1990)$.
11. Y. Inai, K. Hasegawa, T. Hirabayashi, and K. Yokota, Polym. J., 28, 238 (1996).

12. Y. Inai, K. Hasegawa, T. Hirabayashi, and K. Yokota, Polym. J., 28, 440 (1996).

13. Y. Inai, S. Kurashima, Y. Okado, T. Hirabayashi, and K. Yokota, Bull. Chem. Soc. Jpn., 69, 1687 (1996).

14. Y. Inai, T. Ito, T. Hirabayashi, and K. Yokota, Biopolymers, 33, $1173(1993)$.

15. Y. Inai, T. Ito, T. Hirabayashi, and K. Yokota, Polym. J., 27, 846 (1995).

16. F. Momany, R. F. McGuire, A. W. Burgess, and H. A. Scheraga, J. Phys. Chem., 79, 2361 (1975).

17. M. Sisido, private communications.

18. Y. Beppu, Comput. Chem., 13, 101 (1989).

19. J. A. Nelder and R. Mead, Comput. J., 7, 308 (1965).

20. G. Nemethy, M. S. Pottle, and H. A. Scheraga, J. Phys. Chem., 87, 1883 (1983).

21. K. R. Rajashnkar, S. Ramakumar, and V. S. Chauhan, J. Am Chem. Soc., 114, 9225 (1992).

22. M. R. Ciajoro, A. Tuzi, C. R. Pratesi, A. Fissi, and O. Pieroni, Biopolymers, 30, 911 (1991).

23. K. K. Bhandary and V. S. Chauhan, Biopolymers, 33, 209 (1993).

24. M. R. Ciajoro, A. Tuzi, C. R. Pratesi, A. Fissi, and O. Pieroni, Biopolymers, 32, 717 (1992).

25. S. S. Zimmerman, M. S. Pottle, G. Nemethy, and H. A. Scheraga, Macromolecules, 10, 1 (1975)

26. N. Nishi, T. Naruse, K. Hagiwara, B. Nakajima, and S. Tokura, Mackromol. Chem., 192, 1799 (1991).

27. M. Oka, private communications.

28. M. Oka and T. Hayashi, Polym. Prep. Jpn., 44, 3325 (1995).

29. O. Pieroni, G. Montagnoli, A. Fissi, S. Merlino, and F. Ciardelli, J. Am. Chem. Soc., 87, 6820 (1975).

30. N. Harada, S. L. Chen, and K. Nakanishi, J. Am. Chem. Soc. 97, 5345 (1975).

31. A. Bharadwaj, A. Jaswal, and V. S. Chauhan, Tetrahydrofuran, 48, 2691 (1992).

32. O. Pieroni, A. Fissi, R. M. Jain, and V. S. Chauhan, Biopolymers, 38, 97 (1996).

33. J. Poznanski, A. Ejchart, K. L. Wierzchowski, and M. Ciurak, Biopolymers, 33, 781 (1993), and references therein.

34. I. L. Karle, J. L. Flippen-Anderson, K. Uma, H. Balaram, and P. Balaram, Biopolymers, 29, 1433 (1990). 